W. H. van HEEK points his finger at the B.C. Forest Service and asks

\section{"BCFS - where is your common sense?"}

You are known for good forest management, you are fortunate to administer a forest resource of large magnitude with a quality of timber and a variety of species that many foresters in Canada and outside are envious of. You have established a sustained yield policy for British Columbia and you administer Tree Farm Licences and Public Sustained Yield Units.

Within this framework you have established good inventory records, improved utilization of the forest and have forest protection and reforestation policies that appear necessary and justified to maintain adequate growing stock on your forest land.

Why - you might ask should I start with such praise of aspects that are well-known among foresters? Because, as a forester, I am concerned that the B.C. Forest Service is in the process of implementing policies and cutting permit requirements that are not in line with its otherwise sound forestry practices. Public pressure is used as an excuse to justify actions and requirements that are not necessary and that do not contribute to the basic objectives of forest management in British Columbia at this time. Rules and regulations are being created in an atmosphere of paper work and red tape without due consideration as to how they really apply in the field and their true bearing on silvicultural aspects.

We foresters all know the objectives of good forest management; most of us will agree to these as far as they are related to the public and the country's interest. It is essential that the most important renewable resource (in present economic terms) be managed according to sound principles.

In British Columia we are opening up a vast virgin forest. In order to meet the requirements of sustained yield, we must harvest, protect and renew the resource. Only on the best sites in the southern regions of the province are slightly more intensive forestry practices, such as juvenile spacing and genetic improvement of Douglas-fir, being introduced gradually.

The Prince Rupert Forest District is a typical example of as yet non-intensive forest management area. Why, then, are you creating clauses and requirements that do not contribute to good forest management?

Are you really convinced that non-commercial cover willow and alder patches along streams should be treated as productive forest land for coniferous tree species? Rivers and creeks have their own distinctive environment and poor drainage; seasonal flooding as well as beaver activities are natural reasons for the existence of this type of vegetation. Can you say that you have successfully destroyed this vegetation and rehabilitated these areas by planting coniferous tree species? You know that the total area of these fringes constitutes a very minor percentage of the total acreage of productive forest land. You also know that we want to conserve streams in such a way that they remain suitable spawning grounds for fish, undisturbed and with even temperatures. Why then, do you insist on cutting this vegetation, encourage brush development and hope for natural or insist on artificial restocking of these areas of doubtful productive forest land? Why insist on the destruction of alder and its vigorous spruce understory while this is the natural sequence of forest establishment? You are telling industry to spend money and effort for destructive practices on non-forest land which, in this case, contributes beneficially to natural spawning conditions. Some alder destruction on the coast may be necessary but why apply it to all cutting areas adjacent to streams? And can alder not be considered as a future merchantable tree species?

You are trying to manage this mostly non-productive forest land, usually poorly drained, on an intensive basis and the odds are against you on purely silvicultural and environmental grounds. Why don't we spend our efforts on truly productive forest land where we have thousands of acres that need treatment much more urgently and where we have not yet met the required minimum standards of restocking and spacing?

Why do you insist on the complete cutting of small swamp and lake areas within settings? A swamp as well as its immediate fringes of stunted trees constitute non-productive forest land. Why do we not leave this low site land untouched so that its natural status is undisturbed and remains a shelter for wildlife? Why do you insist on the cutting of scrub type timber on rock outcrops within a setting? Can we not leave these patches of timber undisturbed instead of creating a mess and possibly burning it? You do not restock areas under site index 80 . So where is the sense in destroying the existing cover in the first place? Granted, you will argue about wind damage, inferior genetic value of these fringe trees as related to natural restocking, possibly damage to these fringes during slashburning. But stunted trees along swamp edges are generally wind firm. Genetic values of these trees are very likely the same as those of the total existing forest and as it is, we accept natural regeneration from any source at present over large areas. Damage during slashburning can occur but is it a valid reason to justify destruction as a set policy?

Then you talk about the change in microclimate and aesthetic values as justification not to cut blocks of timber even after surrounding areas have been abated and regenerated. Of course, changes in microclimate occur wherever forestry is being practised and who determines if this is good or bad and to what degree? Aesthetic values can be assessed in a hundred different ways, depending who is the judge. What is wrong with the aesthetic value of immature replacing old growth forest? If nonproductive forest land, swamp edges and streamside vegetation 
are left uncut as mentioned earlier and certain areas of historical, recreational or biological value set aside deliberately, then we do contribute to aesthetic values in a positive way.

You are undermining the challenge for foresters to practice sensible basic forestry. You are trying to work against nature and the cost of tools and skills required to change these environmental conditions are beyond the scope of the dollar allocated by the Government. We are not yet ready for this type of work in most parts of the province.

Granted, industry often is guilty of actions that are not acceptable anymore. There should be no excuse for trespasses, i,nproper utilizations and unnecessary destruction. You must insist on slash reduction and reforestation practices but it is unacceptable that you ask for meaningless destruction of natural conditions in the forest and along streams and require unnecessary expenditures from industry.

As for the requirement to yard tree tops in order to reduce slashburning, this is a very controversial and potentially costly subject. We must not lose sight of the fact that in the overmature wet coastal forest areas slash is beneficial for shading and erosion control and successful natural regenerated areas prove this. We should not be afraid to reduce the amount of broadcast burning in these areas. But also, the public should know and have to accept that in certain extreme slash situations, disposal by broadcast burning is the only economical way to prepare areas for a new crop., Again, this new clause could develop into an unmanageable monstrosity of red tape and the forestry profession should very carefully examine which policies are workable and which do not really make sense.

Are we supposed to be foresters, seriously implementing sound forestry practices or are we the victims of a complex society that regulates beyond sound reasoning?

Come on foresters and B. C. Forest Service - let us use some common sense!
Letters

\section{CREDIBILITY}

May I add my commendations to those already expressed on the new and improved Forestry Chronicle. I thought the February issue was particularly well-supplied with material for fruitful discussion. Was it only by coincidence that a number of related comments appeared simultaneously?

In his admirable article, G.W.I. Creighton conceded that the companies in Nova Scotia had not always been above reproach in their cutting practices. Is this why there is the credibility gap regretted by G.F. Weetman - because private practice has not always been in accord with public utterance? Dr. Creighton also showed how political considerations had affected the development of a sound forest policy. How far are professional foresters guilty by their silence in not protesting this sort of compromising of professional standards? Are we, as D.C.F. Fayle suggested, in a different context, afraid to 'tell it as it is'? Perhaps one should ask can we afford not to tell it like it is. Have we, as a profession, really thought out to whom we are ultimately responsible? And if so, are we content with the situation described by Dr. G. Herzberg, presumably including the Canadian Forestry Service, where four people direct each scientist into mission-oriented research? Are our forest scientists so incompetent that they require that amount of supervision? Is the forestry education mentioned by $\mathrm{Dr}$. J. W. Ker doing an adequate job of preparing graduates to be thoughtfully and professionally articulate in today's and tomorrow's world of environmental concern?

It seems to me, Sir, that you have started enough controversy to fill the remainder of Volume 48 , or are foresters too reluctant to put their viewpoints down on paper?

\section{R.M. Strang}

Edmonton, Alta.

\section{SYSTEMIZED SILVICULTURE}

Prof. Thirgood in essence, wants (Forest. Chron. 47:308-310) new Silvicultural Systems that take cognizance of new technologies of harvesting and reproduction. This is a very desirable end. However, the matter should stem from the definition of a "silvicultural system" which is broadly acceptable and generally tenable. This definition is not forthcoming. Forestry literature in India is already replete with claims and counterclaims by foresters as originators of new silvicultural systems simply because they had modified the prescribed cultural prescriptions of forests based on local needs. Troup had envisaged modifications by In- dian foresters, but not mushrooming of new silvicultural systems that differed from each other by a hair's breadth.

The concept of a 'system' presupposes limits and conditions. But if local needs and technologies change rapidly, as they do in the present day world, devising new silvicultural systems is a futile, if not an impossible, excercise.

In the educational field confusion is rampaging already. Unconstructed class, 'team-teaching', individualized instruction, 'group-progress' etc., and many more similar slogans have left the teacher and the taught confounded.

In Forestry, either we have a system, or don't have a system. A very loosely defined silvicultural system is no system at all. At least it is not usable by all. Conversely, there is also a risk of 'mass-producing' of silvicultural systems because equipment or local needs differ markedly. A silvicultural system must be definitive, be applicable over a large region, and must have a dimension of 'time'.

\section{Prem Kumar}

Department of Lands and Forests Edmonton, Alta.

\section{ABOUT AXES}

In his paper on systemized silviculture, Jack Thirgood (Forest. Chron. 47:308-310) mentions the broad axe as being a tool of the silviculturist/harvester. While used in the general harvesting operation during the early days of logging in eastern Canada, the broad axe was a hewing instrument used to produce square timber. Broad axes generally weighed from 8 to 10 pounds, had a chisel cutting edge and a short offset handle about 24 inches long.

Single and double bit axes weighing from 3 to 4 pounds were used to harvest trees until about 1870 when the cross cut saw was introduced into the felling operation. Prior to this date the saw had only been used to buck the tree bole into log lengths.

\section{T.G. Honer}

Ottawa, Ont.

\section{OUR MISTAKE}

Thank you for noticing my appointment to the Eastern Rockies Forest Conservation Board in the February issue of the "Chronicle".". May I, however, point out that I am not the chairman, but simply the member of the Board appointed by the Government of Canada. Two members are appointed by the Government of Alberta, one of whom, Mr. J. R. H. Hall (also a member of the C.I.F.), is chairman.

On a rather different matter, I was beginning to wonder whether the lead "Forum" item in the October, 1971 number, entitled "Policy Castigated", was ever going to evoke a response. It was indeed a pleasure, therefore, to see 